\title{
Coefficient of Performance Stabilisation in Ground Source Heat Pump Systems
}

\author{
Jerzy Wołoszyn ${ }^{* 1}$, Andrzej Gołas' \\ ${ }^{1}$ AGH University of Science and Technology, Faculty of Mechanical Engineering and Robotics, \\ 30 Mickiewicza Av., 30-059, Krakow, Poland \\ e-mail: jwoloszy@agh.edu.pl \\ ${ }^{2}$ AGH University of Science and Technology, Faculty of Mechanical Engineering and Robotics, \\ 30 Mickiewicza Av., 30-059, Krakow, Poland \\ e-mail: ghgolas@cyf-kr.edu.pl
}

\begin{abstract}
Cite as: Wołoszyn, J., Gołaś, A., Coefficient of Performance Stabilisation in Ground Source Heat Pump Systems, J. sustain. dev. energy water environ. syst., 5(4), pp 645-656, 2017, DOI: http://dx.doi.org/10.13044/j.sdewes.d5.0173
\end{abstract}

\begin{abstract}
The number of installations with ground source heat pumps is steadily increasing. As they involve high investment costs, they require deliberate action and analysis. Research on the influence of design, materials and operating parameters on their coefficient of performance becomes of great importance. In this article the authors propose a new ground source heat pump system with horizontal ground heat exchanger and subsurface irrigation system. In order to examine the possibility of applying the system, the influence of soil moisture content on the heat pump coefficient of performance was investigated in this research. Conducting research on the real object is extremely expensive, so it was decided to conduct simulation studies using the finite element method. The presented results of research confirm that the soil moisture content has the greatest impact on the heat pump system coefficient of performance. The developed ground source heat pump system with subsurface irrigation system allow to reduce the length of ground heat exchanger loop.
\end{abstract}

\section{KEYWORDS}

Ground source heat pump system, Coefficient of performance, Soil moisture content, Subsurface irrigation system, Quasi3D modelling.

\section{INTRODUCTION}

Growing demand of energy requires alternative energy sources. Among the equipment for effective energy conversion are heat pumps. For its operation the heat pump requires a heat source, for example: air, water or soil. The heat is transferred from the heat source via a heat exchanger, which in the present case is placed in the ground. The whole system is called Ground Source Heat Pump (GSHP). The different types of GSHPs are open loop and closed loop. The heat exchanger could be vertical or horizontal, however the most widely used are vertical heat exchangers with closed loop [1]. The vertical heat exchangers are expensive although they are very efficient and drilling costs vary depending on the lithological profile of the rock mass. Hence a

\footnotetext{
${ }^{*}$ Corresponding author
} 
compromise is made between higher efficiency and cost in horizontal ground heat exchangers which require a larger ground area. In horizontal heat exchangers embedded in soil, long pipes are installed under freezing zone at a depth of 1 to 2 metres through which heat transfer fluid flows and exchanges heat to or from soil [2]. Broad application of this technology has contributed to recent research concerning heat pump with vertical and horizontal heat exchanger. For example, Benli [3] made a performance comparison between horizontal and vertical source heat pump systems. A detailed literature review with possible applications and challenges of optimal control was made in Soni et al. [4] and Atam and Helsen [5]. Babak et al. [6] considered the possibility of heat pump use in hot water supply systems. Sivasakthivel et al. [7] optimized eight important parameters of Ground Heat Exchanger (GHE). The presented results showed a $15.17 \%$ reduction in the length of ground heat exchanger, 2.5\% increase in Coefficient of Performance (COP) and $17.1 \%$ reduction in thermal resistance of GHE. Hanuszkiewicz-Drapała and Składzień in [8], a mathematical model for Vapour-Compressor Heat Pump (VCHP) ground heat exchanger systems was briefly presented and the cumulative energy and ecological results of the application of VCHP-GHE systems were estimated. Kupiec et al. [9], presented the mathematical model of a horizontal ground heat exchanger. Luo et al. [10], presented ground investigations for different types of GSHP systems. Based on recently published literature [11], a simple heat and moisture transfer model to predict ground temperature for shallow ground heat exchangers was considered. The model includes the influence of water content on soil thermal properties. Ji et al. in [12], an improved 3-D line source model was developed. It allowed calculating the soil temperature distribution and inlet/outlet fluid temperature. Shang et al. [13] presented an unsaturated three-dimensional model to study a ground source heat pump system based on moisture porous theory and soil moisture dynamics. Based on literature search, it could be concluded that modelling is an important area for study of vertical or horizontal source heat pump systems. It happens because conducting research on the real objects could be extremely expensive.

There are a number of parameters which determine the efficiency of a horizontal heat exchanger and they can be classified as:

- Basic design and material parameters;

○ Diameter of the heat exchanger pipe;

- Wall thickness of the pipe and the associated thermal resistance;

- Distance between pipes axes;

- Thermal conductivities of the soil and the pipe;

- Moisture content of the soil;

- Heat exchanger length;

- Arrangement in the subsurface;

Infiltration and ground water flow;

- Operating parameters;

○ Type of flow (turbulent or laminar);

- Flow fluid rate;

- Temperature of the fluid;

- Distance from the heat consumers;

- Type of work;

- Local climatic conditions.

So far, studies allow only a general statement that the thermal conductivity of the soil increases with increasing moisture content of the soil determined by volume or by mass $[14,15]$. However, there is no research to indicate the soil moisture at which a specified COP is obtained. For this reason, the characteristic feature of the Heat Pump (HP) with horizontal GHE is variable COP, which is dependent on weather conditions. 
After literature review, it became clear that there is a need to conduct sensitivity analysis of GSHP performance on soil moisture content. Most of the research has focused only on the geometrical parameters. For example, Nam and Chae [16] conducted research at different conditions of design and installation with variables such as pipe spacing, installation depth, pipe diameter, circulation water temperature, flow rate, and operation condition. In work presented by Congedo et al. [17], a comparative analysis of three types of horizontal ground heat exchangers, to be coupled with water to water heat pumps, has been performed. Further, Simms et al. [18] examined the annual performance of horizontal ground heat exchanger in soils with heterogeneous thermal conductivity. In work by Wołoszyn and Gołaś [19], the authors conducted the sensitivity analysis of efficiency of thermal energy storage on selected rock mass and grout parameters using the design of experiments method.

In the present paper, the authors propose a new GSHP system with horizontal ground heat exchanger and subsurface irrigation system (Figure 1). In the proposed system, the method of stabilization of the HP COP with horizontal ground heat exchanger (7) is as follows. Soil moisture sensors (3) measure the volumetric water content of soil layer (8) between the horizontal ground heat exchanger (7), and the irrigation system (5). When the volumetric water content decreases below $15 \%$, the control system (1) will run the irrigation system (5). The temperature sensors (4) are located near irrigation system (5) to measure soil temperature above GHE (7) and turn off the installation in case the temperature decreases below $0{ }^{\circ} \mathrm{C}$.

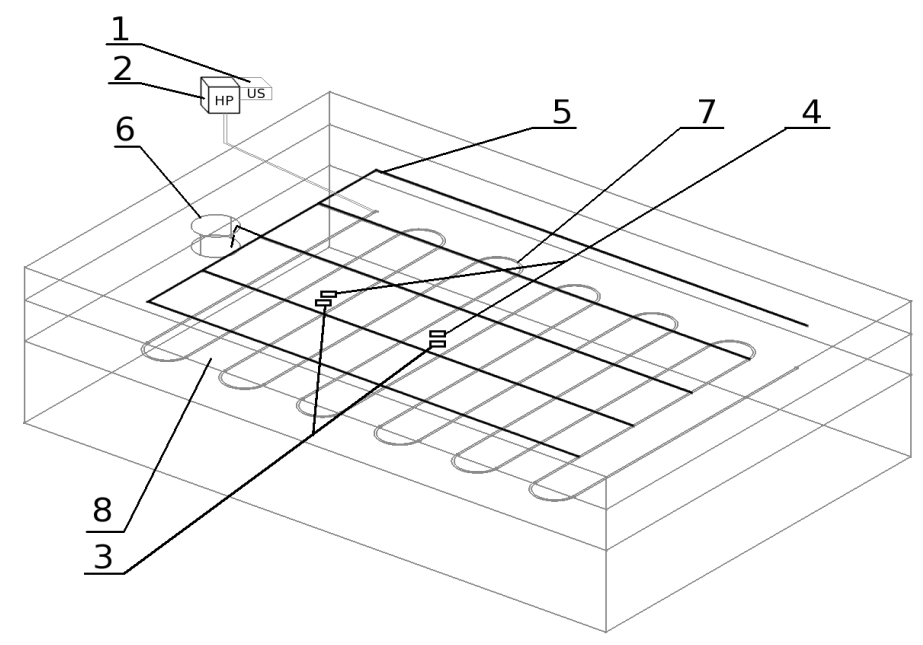

Figure 1. New GSHP system with horizontal ground heat exchanger and subsurface irrigation system: control unit (1), heat pump (2), soil volumetric water content probes (3), temperature sensors (4), irrigation system (5), water reservoir (6), ground heat exchanger (7), soil (8)

In order to verify the proposed solution, the influence of soil moisture content on the HP COP is examined. For the given problem, conducting experiments are very expensive while $3 \mathrm{D}$ numerical simulations are time-consuming, therefore the quasi3 $\mathrm{D}$ heat transfer model was used.

\section{OBJECTIVES OF THE RESEARCH}

The objectives of the research are: two configuration of horizontal GHE, which consists of two basic elements: geological medium and heat exchanger, which links energy source with consumer (Figure 2). The calculations were carried out for the soil of the volume of respectively, $7,779 \mathrm{~m}^{3}$ and $8,316 \mathrm{~m}^{3}$. The first configuration consist of 16 GHE loops with a total length $L=480 \mathrm{~m}$, and the second consist of $20 \mathrm{GHE}$ loops with a total length $L=600 \mathrm{~m}$. 
Detailed parameters of horizontal GHS are as below:

- Outer diameter of heat exchanger pipe $d_{\mathrm{p}, \mathrm{o}}=40 \mathrm{~mm}$;

- Thickness of pipe wall $g=3.7 \mathrm{~mm}$;

- Length of heat exchanger pipe for the first GHE, $L 1=480 \mathrm{~m}$;

- Length of heat exchanger pipe for the second GHE, $L 2=600 \mathrm{~m}$;

- Distance between pipe axes, $e=0.55 \mathrm{~m}$.

To achieve the aim of this work, the steady state analysis was conducted assuming average annual soil temperature.

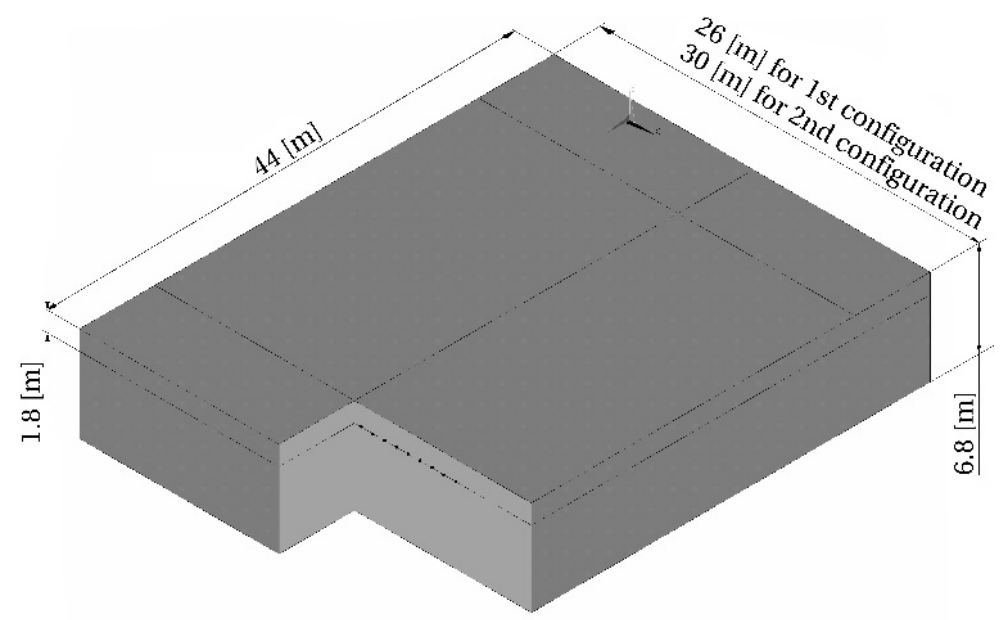

Figure 2. Assumed computational domain

\section{MATHEMATICAL DESCRIPTION}

Heat transport in a horizontal ground heat exchanger is described by partial differential equations. Because constant parameters of the system have been considered, steady state conditions were analysed. Therefore, other influential parameters like specific heat and density were not taken into account. Based on literature review $[14,15]$, it was assumed that the thermal conductivity of the ground was a function of moisture content of the ground. In this case, the heat transport in the ground was derived from Fourier's law and conservation of energy, which present a partial differential equation of steady-state heat conduction eq. (1). Evaporation and seepage of water has been neglected. To describe the heat transport in the fluid and in the pipe the modified quasi3D model [20, 21] was used. Eq. (2) presents a one-dimensional convection-conduction model:

$$
\begin{gathered}
\frac{\partial}{\partial x}\left(\lambda_{\mathrm{s}}(w) \frac{\partial T_{\mathrm{s}}(x, y, z)}{\partial x}\right)+\frac{\partial}{\partial y}\left(\lambda_{\mathrm{s}}(w) \frac{\partial T_{\mathrm{s}}(x, y, z)}{\partial y}\right)+\frac{\partial}{\partial z}\left(\lambda_{\mathrm{s}}(w) \frac{\partial T_{\mathrm{s}}(x, y, z)}{\partial z}\right) \\
+b_{\mathrm{fs}}\left(T_{\mathrm{f}}(z)-\left.T_{\mathrm{s}}(z)\right|_{\mathrm{fs}, \mathrm{wall}}\right)=0 \\
\rho_{\mathrm{f}} C_{\mathrm{f}} u_{\mathrm{f}} \frac{\partial T_{\mathrm{f}}(z)}{\partial z}-\frac{\partial}{\partial z}\left(\lambda_{\mathrm{f}} \frac{\partial T_{\mathrm{f}}(z)}{\partial z}\right)-b_{\mathrm{fs}}\left(T_{\mathrm{s}}(z)-T_{\mathrm{f}}(z)\right)=0
\end{gathered}
$$

In order to determine the heat transfer coefficient $b_{\mathrm{fs}}$ between fluid and soil, the thermal resistance was calculated. Thermal resistance is defined on the basis of the material and geometrical parameters of the exchanger. Thermal resistance between a fluid and soil is defined by convection of the heat carrier within the pipe element and heat conduction through the pipe wall. It is a classical example of heat transport through a cylindrical wall. The heat transfer coefficient $b_{\mathrm{fs}}$ is calculated according eq. (3): 


$$
b_{\mathrm{fs}}=\frac{1}{R_{\mathrm{fs}} L_{\mathrm{fs}}}
$$

where thermal resistance between fluid and soil is defined by eq. (4) and $L_{\mathrm{fs}}$ is the circumference of the pipe:

$$
R_{\mathrm{fs}}=R_{\mathrm{conv}}+R_{\text {cond }}
$$

The thermal resistance due to convection $R_{\text {conv }}$ in the pipe element is described by eq. (5):

$$
R_{\text {conv }}=\frac{1}{\alpha 2 \pi r_{\mathrm{p}, \mathrm{i}}}
$$

where:

$$
\alpha=\frac{N u \lambda_{\mathrm{f}}}{d_{\mathrm{p}, \mathrm{i}}}
$$

Because the Nusselt number $N u$ depends on the type of flow, it was defined in accordance with [22] and modified Gnielinski correlation in the following way as per eq. (7):

$$
N u=\left\{\begin{array}{c}
\frac{\left(\frac{\xi}{8}\right) \times \operatorname{Re} \times \operatorname{Pr}}{1+12.7 \sqrt{\frac{\xi}{8}} \times\left(\operatorname{Pr}^{\frac{2}{3}}-1\right)}\left[1+\left(\frac{d_{\mathrm{p}, \mathrm{i}}}{l_{\mathrm{p}}}\right)^{\frac{2}{3}}\right] \text { for } R e>10^{4} \\
(1-\gamma) \times 4.364+\gamma\left\{\frac{\left(\frac{0.0308}{8}\right) \times 10^{4} \times \operatorname{Pr}}{1+12.7 \sqrt{\frac{0.0308}{8}} \times\left(\operatorname{Pr}^{\frac{2}{3}}-1\right)}\left[1+\left(\frac{d_{\mathrm{p}, \mathrm{i}}}{l_{\mathrm{p}}}\right)^{\frac{2}{3}}\right]\right\} \text { for } 2,300 \leq R e \leq 10^{4}
\end{array}\right.
$$

where $\operatorname{Pr}$ represents the Prandtl number and $R e$, the Reynolds number:

$$
\begin{gathered}
\operatorname{Pr}=\frac{c_{\mathrm{f}} \mu_{\mathrm{f}}}{\lambda_{\mathrm{f}}}, \quad R e=\frac{\rho_{\mathrm{f}} u_{\mathrm{f}} d_{\mathrm{p}, \mathrm{i}}}{\mu_{\mathrm{f}}} \\
\xi=\left(1.8 \log _{10} R e-1.5\right)^{-2} \\
\gamma=\frac{R e-2,300}{10^{4}-2,300} \text { and } 0 \leq \gamma \leq 1
\end{gathered}
$$

Thermal resistance as a result of conduction within the pipe material is determined by the following equation:

$$
R_{\text {cond }}=\frac{\ln \left(\frac{r_{\mathrm{p}, \mathrm{o}}}{r_{\mathrm{p}, \mathrm{i}}}\right)}{2 \pi \lambda_{\mathrm{p}}}
$$

\section{Boundary conditions}

Solving eqs. (1) and (2) requires assuming the boundary conditions. It was assumed that the soil temperature increases with depth according to an average annual soil 
temperature in Krakow, Poland (Figure 3). To simulate external weather conditions, for the top surface of the research model the convection boundary condition was assumed as in eq. (9):

$$
-\lambda_{\mathrm{s}} \frac{\partial T_{\mathrm{s}}}{\partial n}=b_{\mathrm{as}}\left(T_{\mathrm{s}}-T_{\mathrm{a}}\right)
$$

The heat transfer coefficient $b_{\text {as }}$ between air and soil surface equal $b_{\text {as }}=7 \mathrm{~W} / \mathrm{mK}$ with air temperature equal $T_{\mathrm{a}}=280.15 \mathrm{~K}$. For the lateral surface, the Dirichlet boundary condition was assumed and temperature varied with depth in accordance with Figure 3.

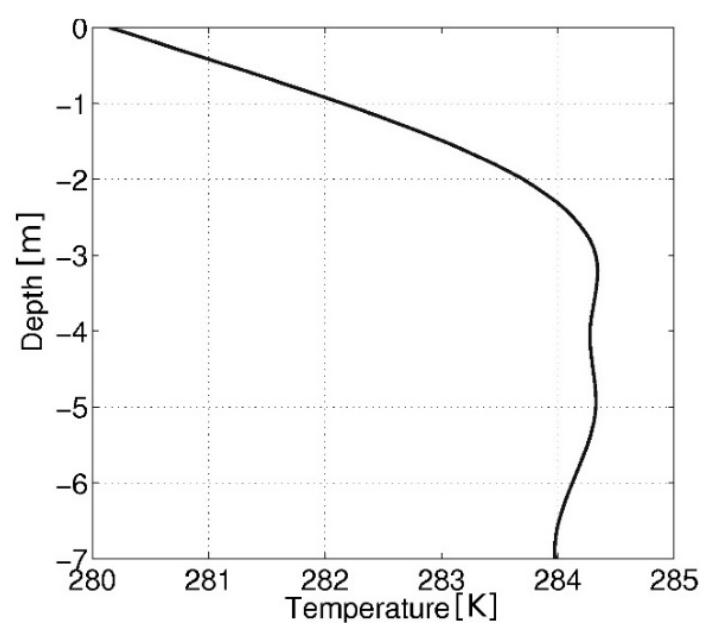

Figure 3. Temperature changed with depth - boundary conditions

As an inlet boundary condition, an annual average inlet temperature of the fluid in the horizontal heat exchanger was assumed $T_{\mathrm{f}}=273.15 \mathrm{~K}$. The fluid velocity $u_{\mathrm{f}}=1 \mathrm{~m} / \mathrm{s}$. Soil thermal conductivity changed with volumetric water content and take values according measurements conduct in [15] and presented in Figure 4 and Table 1. One of the most used fluids in GSHP is a water and glycol mixture. The assumed values of specific thermophysical constants of propylene glycol are as follows: dynamic viscosity $\mu_{\mathrm{f}}=0.0052 \mathrm{~Pa} \mathrm{~s}$, density $\rho_{\mathrm{f}}=1,052 \mathrm{~kg} / \mathrm{m}^{3}$, thermal conductivity $\lambda_{\mathrm{f}}=0.48 \mathrm{~W} / \mathrm{mK}$ and specific heat $c_{\mathrm{f}}=3,795 \mathrm{~J} / \mathrm{kgK}$.

To ensure that the results would converge, a grid independence test was made (Figure 5). The numerical simulation model contains 1,190,280 cells.

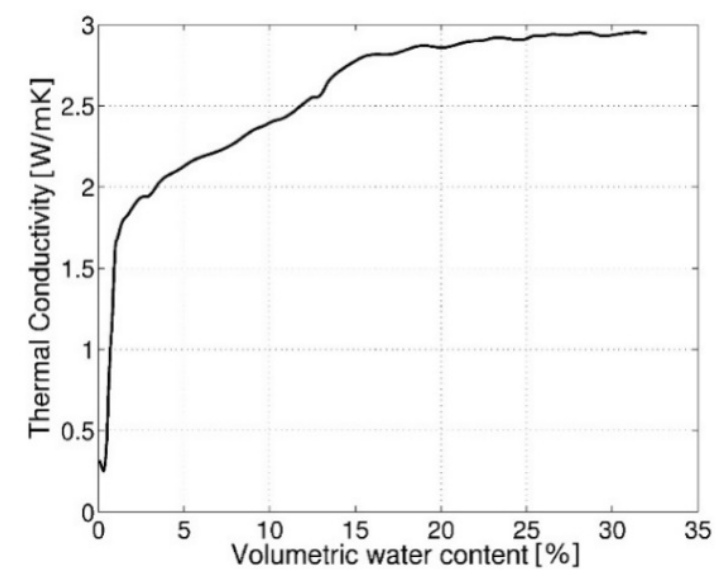

Figure 4. Thermal conductivity in relation to volumetric water content for loosely packed sand [15] 

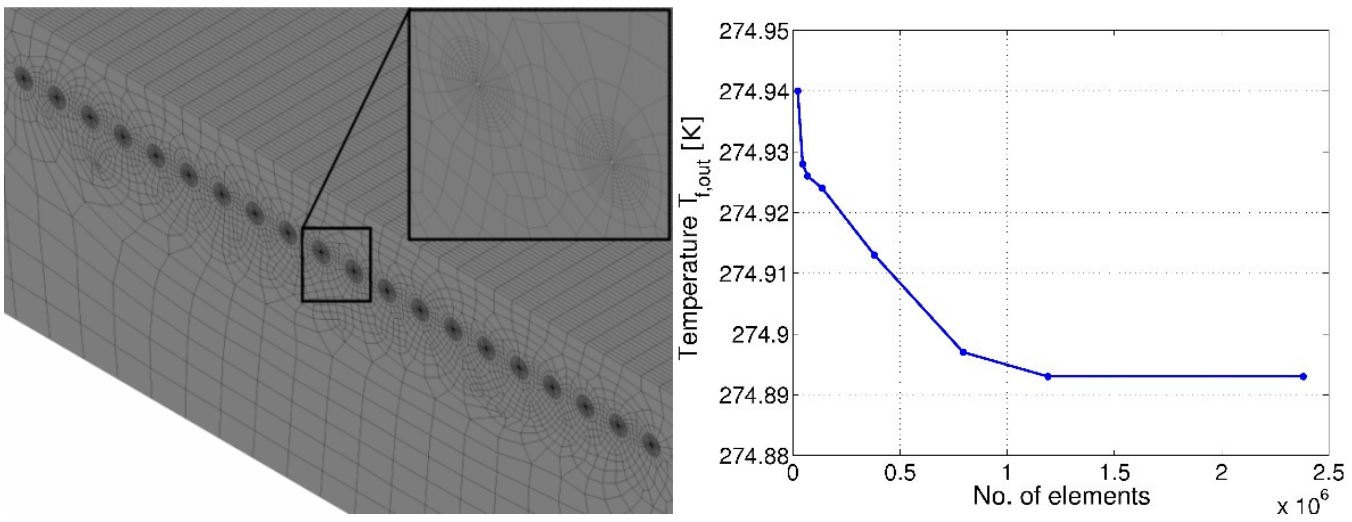

Figure 5. Grid and grid independence test

\section{RESULTS OF NUMERICAL CALCULATIONS}

To realize the aim of this research, the quasi3D numerical model of heat transport was used. The sparse direct solver was used to solve the partial differential equations described by the model. As output parameters the coefficient of heat pump performance was calculated according well known equation as the ratio of the heat removed from the cold reservoir plus the input work to the input work and in the flow system:

$$
\mathrm{COP}=\frac{\dot{Q}_{\mathrm{c}}+\dot{W}}{\dot{W}}
$$

where the removed heat flow from cold reservoir is:

$$
\dot{Q}_{\mathrm{c}}=\dot{m} \times c_{\mathrm{f}} \times \Delta T_{\mathrm{f}}
$$

and mechanical power consumed by the compressor is $\dot{W}=2 \mathrm{~kW}$, e.g., small domestic heat pump system. In the analysed issue it was assumed that the compressor works at constant power.

In Table 1 the variation of soil volumetric water content, thermal conductivity and COP results for the first and second configuration, are shown. The influence of moisture soil content on the heat pump COP was examined. The sensitivity was calculated as derivative $\mathrm{COP}$ and soil volumetric water content according to eq. 12:

$$
\mathrm{COP}_{\text {Sensitivity }}=\frac{d \mathrm{COP}}{d w}
$$

Table 1. COP, soil moisture content and thermal conductivity

\begin{tabular}{cccc}
\hline Volumetric water content [\%] & Thermal conductivity $[\mathrm{W} /(\mathrm{mK})]$ & COP $1^{\text {st }}$ config. $[-]$ & COP $2^{\text {nd }}$ config. $[-]$ \\
\hline 0.07 & 0.2 & 1.3 & 1.3 \\
0.3 & 0.4 & 1.5 & 1.6 \\
0.6 & 0.6 & 1.7 & 1.9 \\
0.62 & 0.8 & 1.9 & 2.15 \\
0.77 & 1.1 & 2.26 & 2.53 \\
0.89 & 1.4 & 2.55 & 2.87 \\
1.7 & 1.8 & 2.9 & 3.29 \\
6.5 & 2.2 & 3.2 & 3.66 \\
12.2 & 2.5 & 3.43 & 3.91 \\
15.55 & 2.8 & 3.64 & 4.16 \\
\hline
\end{tabular}


Figure 6 presents the obtained local sensitivity. As can be seen, the soil moisture content has a significant impact on COP, especially to $1 \%$ of soil volumetric water content. This is because with the increase in soil moisture content, the thermal conductivity increases rapidly.

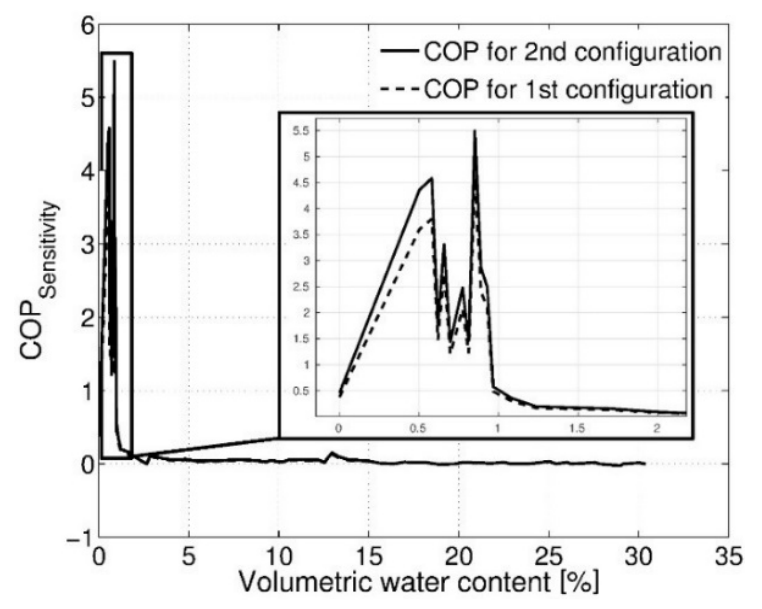

Figure 6. Local sensitivity chart

Figure 7 presents temperature distribution in the ground for thermal conductivity of $0.2 \mathrm{~W} /(\mathrm{mK})$ and $2.8 \mathrm{~W} /(\mathrm{mK})$. Figures 8 and 9 present $\mathrm{COP}$ in relation to thermal conductivity and in relation to soil volumetric water content, respectively. On Figure 8 it can be seen that with the increase of thermal conductivity, the COP increases. It is due to an increase in heat source efficiency. The same occurs in the second heat exchanger configuration $(L=600 \mathrm{~m})$. Presented results confirm the correctness of the calculation. In Figure 9 it can be seen, that in the volumetric water content range of $0-1 \%$ there is a rapid change of COP 1.5-2.8 for the first configuration and 1.5-3.2 for the second configuration. However, for volumetric water content range of $1-30 \%$, the COP changes in the range of 2.8-3.7 and 3.2-4.25, respectively.

\section{Temperature [K]}

for $\lambda_{\mathrm{s}}=2.8 \mathrm{~W} /(\mathrm{mK})$

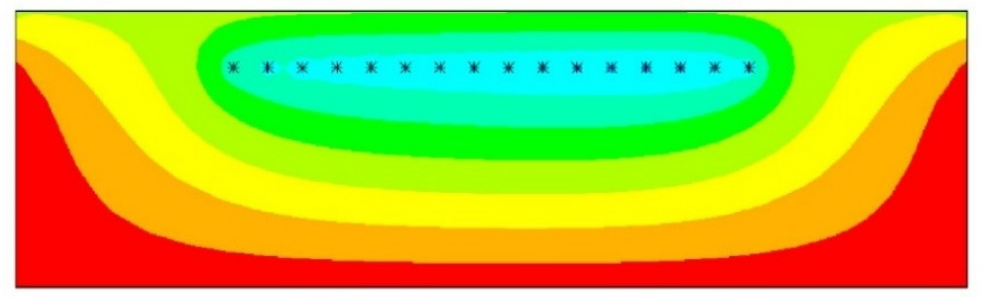

for $\lambda_{\mathrm{s}}=0.2 \mathrm{~W} /(\mathrm{mK})$
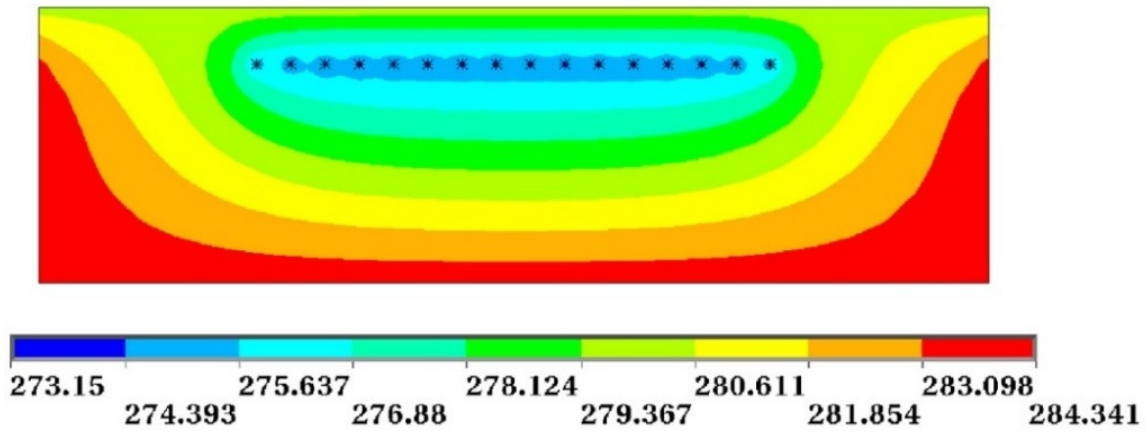

Figure 7. Temperature distribution in the ground for $1^{\text {st }}$ configuration 

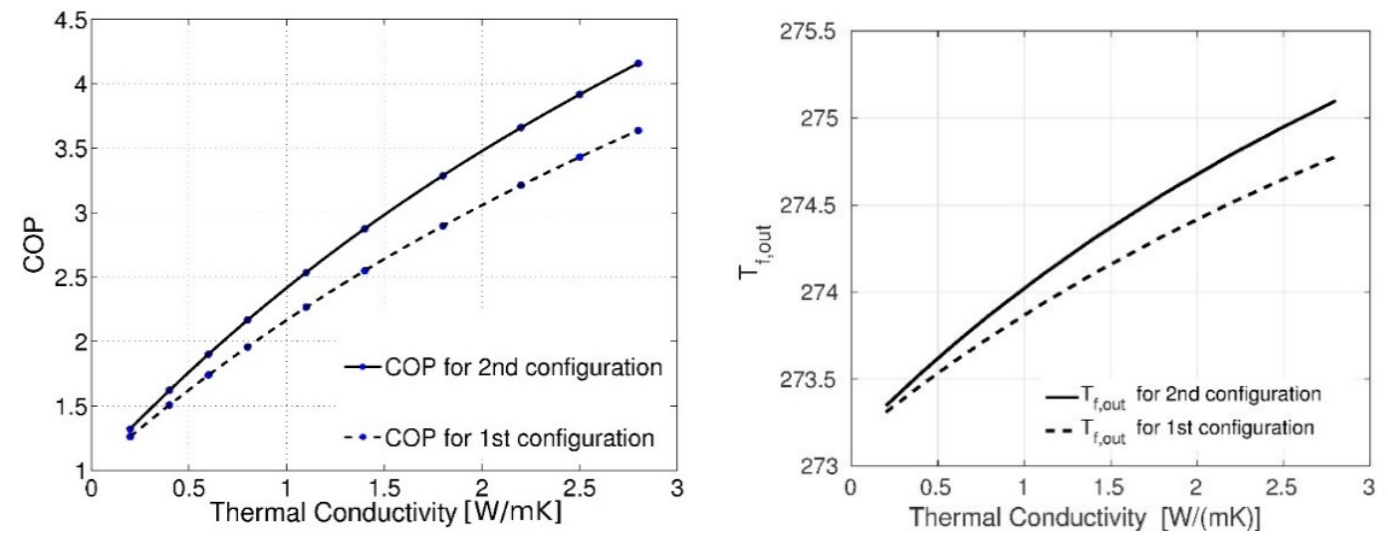

Figure 8. COP and fluid output temperature in relation to thermal conductivity

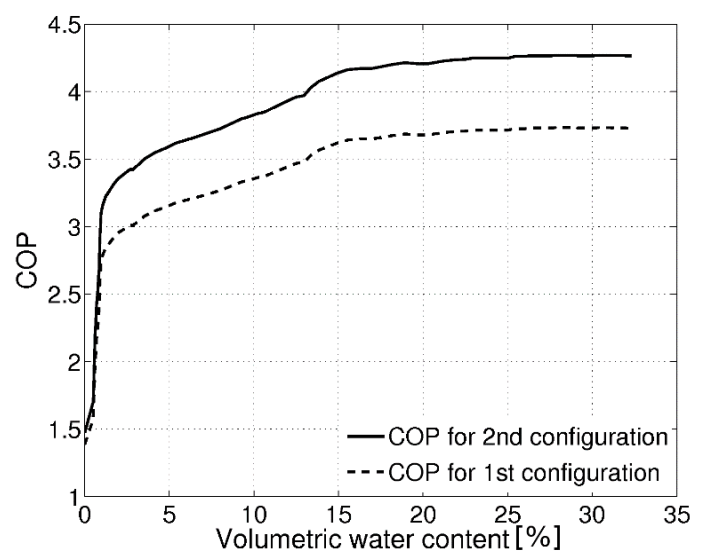

Figure 9. COP in relation to soil volumetric water content

\section{CONCLUSION}

In this work a new numerical heat transport model in horizontal heat exchanger was described. Work begins from the theory concerning the construction of a one dimension fluid-thermal finite element. In order to obtain a more accurate model, the soil was divide for 3D element. The calculations were performed using an Intel Quad $2.33 \mathrm{GHz}$ processor. The soil moisture content has a significant impact on COP, especially to $1 \%$ of soil volumetric water content. This is because increasing soil moisture content rapidly grow the thermal conductivity. As soil, a loosely packed sand was assumed. Proposed new GSHP with irrigation system as way to regulate soil moisture content reduces the amount of used GHE loop according to the required value of HP COP. If the volumetric water content is constant and equal about $14 \%$ the GHE loop will be shorter about $20 \%$ to required $\mathrm{COP}=3.5$. It should be borne in mind that the negative external air and soil temperature will be reduced energy efficiency of the installation due to the lack of soil irrigation.

\section{NOMENCLATURE}

$b$

$c$

$d$

$e$

$g$

$L, l$

$\dot{m}$ heat transfer coefficient

specific heat

diameter

distance between pipes axes

thickness of pipe wall

length

mass flow

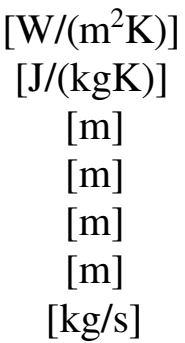




$\begin{array}{llc}\dot{Q} & \text { heat flow } & {[\mathrm{W}]} \\ R & \text { thermal resistance } & {[(\mathrm{mK}) / \mathrm{W}]} \\ r & \text { radius } & {[\mathrm{m}]} \\ S & \text { sensitivity } & {[-]} \\ T & \text { temperature } & {[\mathrm{K}]} \\ u & \text { velocity } & {[\mathrm{m} / \mathrm{s}]} \\ w & \text { soil volumetric water content } & {[\%]} \\ \dot{W} & \text { power } & {[\mathrm{W}]} \\ x, y, z & \text { coordinates } & {[\mathrm{m}]}\end{array}$

\section{Greek letters}

$\begin{array}{llc}\alpha & \text { heat transfer coefficient } & {\left[\mathrm{W} /\left(\mathrm{m}^{2} \mathrm{~K}\right)\right]} \\ \lambda & \text { thermal conductivity } & {[\mathrm{W} /(\mathrm{mK})]} \\ \rho & \text { density } & {\left[\mathrm{kg} / \mathrm{m}^{3}\right]} \\ \mu & \text { dynamic viscosity } & {[\mathrm{Pa} \mathrm{s}]}\end{array}$

\begin{tabular}{ll}
\multicolumn{1}{c}{ Subscript } & \\
$\mathrm{a}$ & air \\
$\mathrm{c}$ & cold reservoir \\
cond & conduction \\
conv & convection \\
$\mathrm{d}$ & heat source \\
$\mathrm{f}$ & fluid \\
$\mathrm{g}$ & heat sink \\
$\mathrm{i}$ & in, inner \\
$\mathrm{o}$ & out, outer \\
$\mathrm{p}$ & pipe \\
$\mathrm{s}$ & soil
\end{tabular}

\section{Abbreviations}

$\begin{array}{ll}\text { COP } & \text { Coefficient of Performance } \\ \text { GHE } & \text { Ground Heat Exchanger } \\ \text { GSHP } & \text { Ground Source Heat Pump } \\ \text { HP } & \text { Heat Pump } \\ \text { VCHP } & \text { Vapour-Compressor Heat Pump }\end{array}$

\section{REFERENCES}

1. Florides, G. and Kalogirou, S., Ground Heat Exchangers - A Review of Systems, Models and Applications, Renewable Energy, Vol. 32, No. 15, pp 2461-2478, 2007, https://doi.org/10.1016/j.renene.2006.12.014

2. Kavanaugh, S. P. and Rafferty, K., Ground Source Heat Pumps and Design of Geothermal Systems for Commercial and Institutional Buildings, ASHRAE Applications Handbook, USA, 1997.

3. Benli, H., A Performance comparison between a Horizontal Source and Vertical Source Heat Pump System for a Greenhouse heating in the Mild Climate Elazig, Turkey, Applied Thermal Engineering, Vol. 50, No. 1, pp 197-206, 2013, https://doi.org/10.1016/j.applthermaleng.2012.06.005

4. Soni, S. K., Pandey, M. and Bartaria, V. N., Ground Coupled Heat Exchangers: A Review and Applications, Renewable and Sustainable Energy Reviews, Vol. 47, pp 83-92, 2015, https://doi.org/10.1016/j.rser.2015.03.014 
5. Atam, E. and Helsen L., Ground-coupled Heat Pumps: Part 1 - Literature Review and Research Challenges in modeling and Optimal Control, Renewable and Sustainable Energy Reviews, Vol. 54, pp 1653-1667, 2016, https://doi.org/10.1016/j.rser.2015.10.007

6. Babak, T., Duić, N., Khavin, G., Boldyryev, S. and Krajačić, G., Possibility of Heat Pump use in Hot Water Supply Systems, Journal of Sustainable Development of Energy, Water and Environment Systems, Vol. 4, No. 3, pp 203-215, 2016, https://doi.org/10.13044/j.sdewes.2016.04.0017

7. Sivasakthivel, T., Murugesan, K. and Sahoo, P. K., Optimization of Ground Heat Exchanger Parameters of Ground Source Heat Pump System for Space Heating Applications, Energy, Vol. 78, pp 573-586, 2014, https://doi.org/10.1016/j.energy.2014.10.045

8. Hanuszkiewicz-Drapała, M. and Składzień, J., Operation Characteristics of Heat Pump Systems with Ground Heat Exchangers, Heat Transfer Engineering, Vol. 33, No. 7, pp 629-641, 2012, https://doi.org/10.1080/01457632.2012.630269

9. Kupiec, K., Larwa, B. and Gwadera, M., Heat Transfer in Horizontal Ground Heat Exchangers, Applied Thermal Engineering, Vol. 75, pp 270-276, 2015, https://doi.org/10.1016/j.applthermaleng.2014.10.003

10. Luo, J., Rohn, J., Xiang, W., Bertermann, D. and Blum, P., A Review of Ground Investigations for Ground Source Heat Pump (GSHP) Systems, Energy and Buildings, Vol. 117, pp 160-175, 2016, https://doi.org/10.1016/j.enbuild.2016.02.038

11. Chalhoub, M., Bernier, M., Coquet, Y. and Philippe, M., A Simple Heat and Moisture Transfer Model to Predict Ground Temperature for Shallow Ground Heat Exchangers, Renewable Energy, Vol. 103, pp 295-307, 2017, https://doi.org/10.1016/j.renene.2016.11.027

12. Ji, Y., Qian, H. and Zheng, X., Development and Validation of a Three-dimensional Numerical Model for predicting the Ground Temperature Distribution, Energy and Buildings, Vol. 140, pp 261-267, 2017, https://doi.org/10.1016/j.enbuild.2017.01.079

13. Shang, Y., Dong, M., Li, S. and Mu, L., Analysis of a Ground Source Heat Pump System using an unsaturated 3-dimensional Model, Applied Thermal Engineering, Vol. 112, pp 1083-1094, 2017, https://doi.org/10.1016/j.applthermaleng.2016.10.169

14. Nikiforova, T., Savytskyi, Y., Limam, K., Bosschaerts, W. and Belarbi, R., Methods and Results of Experimental Researches of Thermal Conductivity of Soils, Energy Procedia, Vol. 42, pp 775-783, 2013, https://doi.org/10.1016/j.egypro.2013.12.034

15. Smits, K. M., Sakaki, T., Limsuwat, A. and Illangasekare, T. H., Determination of the Thermal Conductivity of Sands under Varying Moisture, Drainage/wetting, and Porosity Conditions-applications in Near-surface Soil Moisture Distribution analysis, Proceedings AGU Hydrology Days 2009, Colorado State University, Colorado, USA, 25-27 March 2009.

16. Nam, Y. and Chae, H., Numerical Simulation for the Optimum Design of Ground Source Heat Pump System using Building Foundation as Horizontal Heat Exchanger, Energy, Vol. 73, pp 933-942, 2014, https://doi.org/10.1016/j.energy.2014.06.108

17. Congedo, P. M., Colangelo, G. and Starace, G., CFD Simulations of Horizontal Ground Heat Exchangers: A Comparison among different Configurations, Applied Thermal Engineering, Vol. 33-34, pp 24-32, 2012, https://doi.org/10.1016/j.applthermaleng.2011.09.005

18. Simms, R. B., Haslam, S. R., Craig, J. R., Impact of Soil Heterogeneity on the Functioning of Horizontal Ground Heat Exchangers, Geothermics, Vol. 50, pp 35-43, 2014, https://doi.org/10.1016/j.geothermics.2013.08.007

19. Wołoszyn, J. and Gołaś, A., Sensitivity analysis of Efficiency Thermal Energy Storage on Selected Rock Mass and Grout Parameters using Design of Experiment Method, Energy Conversion and Management, Vol. 87, pp 1297-1304, 2014, https://doi.org/10.1016/j.enconman.2014.03.059 
20. Wołoszyn, J. and Gołaś, A., Modelling of a Borehole Heat Exchanger using a Finite Element with Multiple Degrees of Freedom, Geothermics, Vol. 47, pp 13-26, 2013, https://doi.org/10.1016/j.geothermics.2013.01.002

21. Wołoszyn, J. and Gołaś, A., Experimental Verification and Programming development of a new MDF Borehole Heat Exchanger Numerical Model, Geothermics, Vol. 59, Part A, pp 67-76, 2016, https://doi.org/10.1016/j.geothermics.2015.10.006

22. Diersch, H.-.G., Bauer, D., Heidemann, W., Rühaak, W. and Schätzl, P., Finite Element modeling of Borehole Heat Exchanger Systems, Part 1, Fundamentals, Computers and Geosciences, Vol. 37, No. 8, pp 1122-1135, 2011, https://doi.org/10.1016/j.cageo.2010.08.003 